\title{
ВОЗРАСТ СУКОРСКОГО СЕЙСМОГЕННОГО ОПОЛЗНЯ ПО ДАННЫМ ОСЛ-ДАТИРОВАНИЯ: ЗНАЧЕНИЕ ДЛЯ ПАЛЕОСЕЙСМОЛОГИИ И ПАЛЕОГЕОГРАФИИ ГОРНОГО АЛТАЯ
}

Деев Е. В., Зольников И. Д., Курбанов Р. Н., Панин А. В., Мюррей А. ., Корженков А. М., Турова И. В., Позднякова Н. И., Васильев А. В.

\begin{abstract}
Аннотация
Методами оптически-стимулированной и инфракрасно-стимулированной люминесценции проведено датирование озерных и формирующихся по ним эоловых песков, а также флювиогляциальных песков из абляционных морен на участке долины р. Чуя, соединяющем Чуйскую и Курайскую впадины Горного Алтая. Полученные даты позволяют заключить, что причиной формирования озера, распространившегося в Чуйскую впадину, стал Сукорский скальный оползень, запрудивший долину Чуи. Он произошел 16 тыс. лет назад в результате землетрясения с интенсивностью не менее IX-X баллов, которое сгенерировал один из активных разломов Курайской зоны. Это наиболее древняя известная дата для землетрясений Курайской зоны разломов. Важно, что крупные сейсмогравитационные структуры в ландшафтноклиматических условиях, подобных району Чуйской и Курайской впадин, могут сохранять в рельефе не менее 16 тыс. лет. Озеро просуществовало до рубежа около 10 тыс. лет назад, после чего постепенно спустилось. Максимальная фаза развития Куюктанарского ледника пришлась на начало морской изотопной стадии 2, а его абляционные морены имеют возраст около 25 тыс. лет. Возраст и хорошая сохранность инверсионных моренных гряд Куюктанарского ледника, холмистого рельефа Сукорского скального оползня, озерных песков в районе плотины согласованно указывают на то, что во время последнего глобального гляциального максимума (порядка 20 тыс.л.н.) из Чуйской котловины не происходило катастрофических сбросов больших объемов воды, порождавших мегапаводки в долинах Чуи и Катуни. Уровень озерного водоема этого времени в Курайской впадине не мог превышать 1750 м абс. Более высокие озерные террасы, прослеживаемые до абсолютных высот 2100-2200 м, должны относиться к более древним озерным этапам. Археологические памятники, расположенные в районе перемычки между Чуйской и Курайской впадинами сформировались в постозерный период. Наиболее древние из них относятся к финалу позднекаменного века.
\end{abstract}

\section{Ключевые слова:}

скальный оползень, обвально-подпрудное озеро, морены, ОСЛ-датирование, МИС 2, палеосейсмология, палеогеография, Горный Алтай 


\title{
ВОЗРАСТ СУКОРСКОГО СЕЙСМОГЕННОГО ОПОЛЗНЯ ПО ДАННЫМ ОСЛ- ДАТИРОВАНИЯ: ЗНАЧЕНИЕ ДЛЯ ПАЛЕОСЕЙСМОЛОГИИ И ПАЛЕОГЕОГРАФИИ ГОРНОГО АЛТАЯ
}

\author{
Е.В. Деев ${ }^{1,2,3}$, И.Д. Зольников ${ }^{2,3,4}$, Р.Н. Курбанов ${ }^{3,5}$, А.В. Панив ${ }^{3,5}$, А. Мюррей ${ }^{6}$, \\ А.М. Корженков ${ }^{7}$ И.В. Турова ${ }^{1,2}$, Н.И. Позднякова ${ }^{1,2}$, А.В. Васильев ${ }^{2,4}$ \\ 1 - Институт нефтегазовой геологии и геофизики им. А.А. Трофимука СО РАН, \\ Новосибирск, Россия \\ 2 - Новосибирский государственный университет, Новосибирск, Россия \\ ${ }^{3}$ - Институт географии РАН, Москва, Россия \\ 4 - Институт геологии и минералогии им. В.С. Соболева СО РАН, Новосибирск, Россия \\ 5 - Московский государственный университет им. М.В. Ломоносова, Москва, Россия \\ ${ }^{6}$ - Орхусский университет, Орхус, Дания \\ 7 - Институт физики Земли им. О.Ю. Шмидта, Москва, Россия
}

Аннотация
Методами $\quad$ оптически-стимулированной $\quad$ и $\quad$ инфракрасно-стимулированной люминесценции проведено датирование озерных и формирующихся по ним эоловых песков, а также флювиогляциальных песков из абляционных морен на участке долины р. Чуя, соединяющем Чуйскую и Курайскую впадины Горного Алтая. Полученные даты позволяют заключить, что причиной формирования озера, распространившегося в Чуйскую впадину, стал Сукорский скальный оползень, запрудивший долину Чуи. Он произошел 16 тыс. лет назад в результате землетрясения с интенсивностью не менее IX-X баллов, которое сгенерировал один из активных разломов Курайской зоны. Это наиболее древняя известная дата для землетрясений Курайской зоны разломов. Важно, что крупные сейсмогравитационные структуры в ландшафтно-климатических условиях, подобных району Чуйской и Курайской впадин, могут сохранять в рельефе не менее 16 тыс. лет. Озеро просуществовало до рубежа около 10 тыс. лет назад, после чего постепенно спустилось. Максимальная фаза развития Куюктанарского ледника пришлась на начало морской изотопной стадии 2, а его абляционные морены имеют возраст около 25 тыс. лет. Возраст и хорошая сохранность инверсионных моренных гряд Куюктанарского ледника, холмистого рельефа Сукорского скального оползня, озерных песков в районе плотины согласованно указывают на то, что во время последнего глобального гляциального максимума (порядка 20 тыс.л.н.) из Чуйской котловины не происходило катастрофических сбросов больших объемов воды, порождавших мегапаводки в долинах Чуи и Катуни. Уровень озерного водоема этого времени в Курайской впадине не мог превышать 1750 м абс. Более высокие озерные террасы, прослеживаемые до абсолютных высот 2100-2200 м, 
должны относиться к более древним озерным этапам. Археологические памятники, расположенные в районе перемычки между Чуйской и Курайской впадинами сформировались в постозерный период. Наиболее древние из них относятся к финалу позднекаменного века.

Ключевые слова: скальный оползень, обвально-подпрудное озеро, морены, ОСЛдатирование, МИС 2, палеосейсмология, палеогеография, Горный Алтай

\section{Введение}

Данные сейсмических сетей дают информацию о сильных землетрясениях в регионах лишь за последнюю сотню лет. К примеру, в Горном Алтае такая сеть развернута лишь в 60-х годах прошлого столетия. Такого периода сейсмологических наблюдений явно недостаточно для корректной оценки долгосрочного сейсмического режима и сейсмической опасности. Для осуществления сейсмостойкого строительства, особенно наиболее ответственных энергетических объектов, требуются данные о сильной сейсмической активности за 10, а то и за 100 тыс. лет (Уломов и др., 2016). При решении этой задачи используются методы палеосейсмологии.

Наиболее важное место в палеосейсмологических исследованиях занимают сейсмотектонические - первичные деформации. Они образуются в эпицентральных зонах сильных сейсмических событий и маркируют выходы сейсмических очагов на дневную поверхность. Первичные деформации представлены поверхностными разрывами. Эти разрывы смещают различные формы денудационного и аккумулятивного рельефа по вертикали, образуя разломные уступы, либо в горизонтальном направлении, образуя более сложные ансамбли структур сжатия и растяжения. К сожалению, примеры исследования такого типа структур на территории Горного Алтая не столь многочисленны (Рогожин, Платонова, 2002; Рогожин и др., 2008; Деев и др., 2018; Деев, 2019; Deev et al., 2017; Turova et al., 2020).

Сильные сотрясения земной поверхности также приводят к значительным гравитационным смещениям: оползням и обвалам в скальных и рыхлых грунтах. Их называют сейсмогравитационными или вторичными деформациями. Чаще всего именно они приводят к максимальным людским и материальным потерям при сейсмических катастрофах, накрывая многометровой массой населенные пункты со всей их инфраструктурой. Оползневые и обвальные тела запруживают речные долины, что приводит к образованию временных озер позади обвальных дамб. Плотины таких озер рано или поздно разрушаются, и вниз по долинам прокатываются сели, уничтожающие абсолютно все на своем пути. Именно крупномасштабные оползни и обвалы многими 
исследователями Горного Алтая традиционно связывались с палеоземлетрясениями (Девяткин, 1965; Бутвиловский, 1993; Рогожин, Платонова, 2002; Агатова и др., 2006; Рогожин и др., 1999, 2008; Rogozhin et al., 1998; Agatova et al., 2014). Правомерность такой корреляции подтвердилась во время Алтайского (Чуйского) землетрясения (27.09.2003 г., Ms = 7.3) на южных границах Чуйской и Курайской внутригорных впадин, когда на линии простирания поверхностных разрывов сформировался оползень объемом 30 млн м ${ }^{3}$ (Рогожин и др., 2007). Целая серия масштабных оползней и обвалов вдоль северных бортов Чуйской и Курайской впадин пространственно связана (рис. 1А-В) с активными структурами Курайской зоны разломов (КЗР). Наиболее крупный Сукорский скальный оползень (рис. 1Б, рис. 2), который может наблюдать любой человек, путешествующий по соединяющей Россию и Монголию автомобильной дороге Р-256 (Чуйском тракту), находится на левом берегу р. Чуя, в районе ее правого притока - р. Куюктанар (Куэхтанар).

Несомненно, оценка возраста самого Сукорского скального оползня является ценнейшей палеосейсмологической информацией для понимания времени сохранностей сейсмогравитационных структур, уточнения интервалов повторяемости сильных землетрясений в Горном Алтае и, как следствие, корректировки оценок его долгосрочного сейсмического режима. Однако, оползневое тело не является единственным четвертичным образованием, которое могло блокировать узкую долину р. Чуя на участке между Чуйской и Курайской впадинами. Прямо напротив оползня расположена троговая долина р. Куюктанар, с которой генетически связано широкое моренное поле (рис. 1А, рис. 2). Е.В. Девяткин (1965) считал, что именно долинный Куюктанарский ледник блокировал долину Чуи в эпоху первого позднеплейстоценового оледенения (по возрасту соответствует морской изотопной стадии (МИС) 4), в результате чего в Чуйской котловине сформировалось ледниково-подпрудное озеро, уровень которого достигал 2100 м. П.А. Окишев $(1972,1982)$ соотносил возраст ледниковой плотины с эпохой МИС 2, или Last Glacial Maximum (LGM). Г.Г. Русанов (1997) в качестве плотины озера, заполнявшего Чуйскую котловину до абсолютных отметок 1800 м, возникшего на этапе деградации оледенения LGM и просуществовавшего до голоцена, рассматривает сейсмогенный Сукорский скальный оползень. Плотина такого озера могла иметь смешанный ледниковооползневой (Бутвиловский, 1993) или моренно-подпрудный (Зольников, Мистрюков, 2008) характер. Соединяя Чуйскую и Курайскую впадину, рассматриваемый узкий участок долины р. Чуя является одним из ключевых объектов для понимания плейстоценовой палеогеографии в связи с вопросами существования крупных ледниково-подпрудных бассейнов во впадинах, резкого сброса их вод с формированием гляциальных суперпаводков в долинах Чуи и Катуни, на предгорной Алтайской равнине (Зольников, 
Мистрюков, 2008; Зольников, 2009; Зольников и др., 2010, 2016; Carling et al., 2002; Rudoy, 2002; Deev et al., 2019; Herget et al., 2020). Как первопричину такого паводка в LGM В.В.Бутвиловский (1993) рассматривал мгновенное разрушение именно ледниковоподпрудной плотины в районе Куюктанара. Наконец, понимание озерной палеогеографии является ключом для оценки нижней возрастной границы археологических памятников территории.

Ряд принципиальных вопросов, касающихся возрастов Сукорского скального оползня, Куюктанарского ледника и его морен, времени формирования и интервала существования подпрудного озерного бассейна, типа озерной плотины может быть решен через датирование озерных песков, сохранившихся сразу выше по течению от тела оползня и поля морен (рис. 2). Полученные ранее возраста для этих песков сильно разнятся: от 14-15 тыс. лет (Шейнкман, 2002) до 250-300 лет (Рогожин, Платонова, 2002). Мы решили разобраться в сложившейся ситуации и через серию новых абсолютных датировок песков, полученных методами оптически-стимулированной люминесценции (ОСЛ) и инфракрасно-стимулированной люминесценции (ИКСЛ), ответить на перечисленные выше вопросы. В анализ также были включены образцы песков из флювиогляциальных прослоев абляционных морен Куюктанарского ледника.

\section{Геология района исследований}

Чуйская $(70 \times 35$ км) и Курайская $(35 \times 20$ км) внутригорные впадины - две самые крупные отрицательные морфоструктуры юго-восточной части Горного Алтая (рис. 1А), выполненные кайнозойскими отложениями мощностью до 1200-1600 м (Девяткин, 1965; Неведрова и др., 2001, 2014). С севера впадины сочленяются с Курайским хребтом (абсолютные высоты до 3400 м) по разломам Курайской зоны. В докайнозойском структурном плане КЗР представляла собой субширотную структуру протяженностью 130 км и шириной до 20 км; этапы ее палеозойско-мезозойской эволюции описаны в (Буслов, 2011; Федак и др., 2011; Буслов и др., 2013; Chikov et al., 2012; Chen et al., 2016).

Между собой Чуйская и Курайская впадины разделены Чаганским (Сукорским) массивом (абсолютная высота 2900 м). В тоже время, между Курайским хребтом и Сукорским массивом (рис. 1А) находится узкая (до 2 км в ширину) тектоническая впадина, в пределах которой долина р. Чуя имеет ящикообразную форму (Русанов и др., 2013). Заложение впадины как грабена связано с кайнозойским развитием КЗР. Грабен начал формироваться в обстановке субширотного сжатия (Delvaux et al., 2013), по крайней мере, в олигоцене, о чем свидетельствуют найденные здесь глины с прослоями бурых углей, относящиеся к олигоцен-нижнемиоценовой кошагачской свите (Бутвиловский, 1993). В 
четвертичном периоде в структуре регионального поля напряжений стало доминировать субмеридиональное сжатие. Поэтому КЗР в настоящее время можно рассматривать (рис. 1A) как транспрессионную положительную цветочную структуру с главным Кубадринским разломом в центре Курайского хребта и системой взбросов и надвигов с северным падением, по которым Курайский хребет надвигается на отложения впадин (Delvaux et al., 2013). На некоторых участках у таких разломов фиксируется еще и правосдвиговая компонента смещения (рис. 1Г). Помимо основных взбросов и надвигов в структуре зоны присутствуют аналогичные оперяющие структуры (рис. 1А) с южным падением (Деев, 2019; Deev et al., 2017; Turova et al., 2020). Не исключено, что в четвертичном периоде Чаганский массив испытывал вращение против часовой стрелки, чем объясняется формирование форбергов вдоль его западной границы (Неведрова и др., 2014).

Сейсмологическими наблюдениям за период, начиная с 60-х годов прошлого столетия, вдоль КЗР зафиксированы землетрясения с $\mathrm{M} \leq 5$ (Лескова, Еманов, 2013; Adija et al., 2003). Однако палеосейсмологическими исследованиями установлено, что с Курайской зоной разломов также связаны поверхностные разрывы палеоземлетрясений с $\mathrm{Mw}=6.6-7.6$ и интенсивностью от VIII до $\mathrm{X}$ баллов по шкале ESI 2007. Палеоземлетрясения произошли около 6.3, 5.8, 3.2, 1.3 тыс. л.н. и, вероятно, во второй половине XVIII века н.э. (Рогожин и др., 2008; Деев, 2028, 2019; Deev et al., 2017; Turova et al., 2020). Подвижки по активным разломам в позднем плейстоцене и голоцене способствовали формированию сопутствующих зон открытой трещиноватости, через которые на поверхность изливались обогащенные углекислотой подземные воды с формированием травертинов, цементирующих различные генетические типы рыхлых отложений (Бутвиловский, 1993; Русанов и др., 2013; Деев, 2018; Kokh et al., 2017).

Склон Курайского хребта вдоль грабена имеет ступенчатое строение. Вдоль нижнего тектонического уступа тянутся прекрасно выраженные треугольные фасеты (рис. 1Д, рис. 2). Север Чаганского массива осложнен системой дугообразных сбросов (рис. 1Е). Таким образом, крутонаклонные борта грабена являются отличными плоскостями для возникновения обвалов и оползней при землетрясениях (рис. 1Б и В, рис. 2), формирования крупных осыпей (рис. 1Ж, рис. 2). Наиболее крупный из сейсмогенных скальных оползней объемом, по разным оценкам, от 30 млн м³ (Русанов, 1997) до 80 млн $\mathrm{M}^{3}$ (Рогожин, Платонова, 2002), сошедший с северного склона горы Сукор, занимает все левобережье Чуи напротив долины Куюктанар (рис. 1А и Б, рис. 2). В составе обломков доминируют в разной степени серпентинизированные ультраосновные породы верхненеопротерозойского чаганузунского комплекса (Федак и др., 2011). Полигенное тело 
оползня наложено на абляционную морену позднеплейстоценового Куюктанарского ледника. Протяженность оползневых масс вдоль левобережного коренного склона долины Чуи достигает 3 км, при максимальной ширине до 1.7 км. В результате формирования оползня долина Чуи оказалась блокированной, и выше плотины образовалось озеро, уровень которого поднимался до 1750-1800 м (Бутвиловский, 1993; Русанов, 1997). В максимум своего заполнения озеро занимало долину Чуи и центральную часть Чуйской

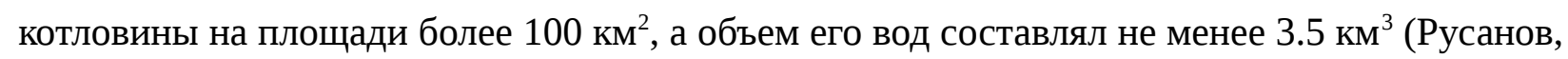
1997).

К востоку от долины Куюктанара на правом и левом берегах Чуи располагается поле озерных песков. На озерных песках в настоящее время активно формируются дефляционные понижения и песчаные дюны. Узкий шлейф эоловых песков тянется по левому берегу Чуи и к западу от долины Куюктанара. В долине Чуи на рассматриваемом участке также выделяются разновысотные эрозионные, эрозионно-аккумулятивные и аккумулятивные террасы.

\section{Методы исследований}

Для решения поставленных задач экскаватором был вскрыт наиболее полный разрез эоловых и озерных песков на всю их мощность, вручную зачищены обнажения абляционных морен с флювиогляциальными песчаными прослоями. В общей сложности было отобрано восемь образцов озерных песков, три образца эоловых песков и три образца песков из флювиогляциальных прослоев абляционных морен для проведения процедуры определения их абсолютного возраста. Процедура датирования, включая определения скорости накопления энергии в отложениях (радиационной дозы) и определения количества накопленной энергии (эквивалентной дозы), выполнена в Северной люминесцентной лаборатории отделения геологических наук Орхусского университета (Nordic Laboratory for Luminescence Dating, Department of Geoscience, Aarhus University, Denmark). Определение эквивалентной дозы проведено путем ОСЛ со стимуляцией голубым светом (Q, SAR-протокол) для кварца и ИКСЛ с нагревом до $50 \mathrm{C}^{\circ}$ (протокол $\left.\mathrm{IR}_{50}\right)$ и $290^{\circ} \mathrm{C}$ (протокол $\mathrm{PIRIR}{ }_{290}$ ) для калиевых полевых шпатов (Murray, Wintle, 2003; Murray et al., 2012). Получение датировок по трем протоколам позволяет выполнять анализ полноты засветки образца и сравнение результатов по степени надёжности. Число измеренных аликвот для разных образцов колеблется от 18 до 26.

Как известно, недостатком люминесцентного датирования является возможное “удревнение” возраста ввиду неполной засветки зерен в ходе геологического транспорта. Особенно эта проблема касается отложений, формирование которых происходило в 
условиях ограниченного доступа света (морены) либо в условиях перемещения значительных объемов материала за короткий промежуток времени. Для определения возможного неполного засвечивания и верификации полученных результатов датирования был предложен метод сравнения итоговых дат, полученных разными протоколами (Murray et al., 2012). Энергия в зернах кварца обнуляется под воздействием света в яркий солнечный день в течение первых десятков секунд, в то время как для более энергетически емких зерен полевых шпатов требуется гораздо большая длительность засвечивания, когда даже после нахождения на свету более суток в кристаллах остается незначительная доза. Таким образом, отложения, в которых и кварц, и полевые шпаты оказываются полностью засвеченными, являются наиболее надежными для выполнения люминесцентного датирования. Близкие измеренные значения накопленной дозы для обоих минералов указывают на длительную засветку и, таким образом, позволяют оценивать надежность датирования. Установлено, что наиболее надежными определениями абсолютного возраста методом ОСЛ являются результаты с соотношением датировок $\mathrm{pIRIR}_{290} / \mathrm{Q}$ в диапазоне 0.9-1.2, для $\mathrm{IR}_{50} / \mathrm{Q}$ - 0.5-0.7 (Murray et al., 2012). При этом, соотношение датировок $\mathrm{pIRIR}_{290} / \mathrm{Q}$ является наиболее важным, так как именно протокол pIRIR 290 позволяет измерить наиболее надежный сигнал в полевых шпатах, а протокол $\mathrm{IR}_{50}$ фиксирует подверженный аномальному затуханию сигнал и измеряется для оценки возможной степени потери энергии в полевых шпатах.

\section{Полученные результаты}

В пределах поля озерных песков, поверх которых развиты эоловые дюны, был выбран участок с наибольшей мощностью песков (рис. 2, рис. ЗА). Здесь (рис. ЗБ) пройдена траншея $\left(50.142390^{\circ}\right.$ с.ш., 88.316860 вскрывшая пески на полную 6-метровую мощность, от кровли песчаной дюны до кровли валунных галечников, слагающих 10-11 метровую речную террасу. В дефляционных понижениях на основе галечных обломков сформированы прекрасные ветрогранники (рис. 3В). В разрезе траншеи выделяется два генетически различных интервала (рис. ЗГ).

(1) Нижние 3.9 м разреза сложены переслаиванием светло-серых среднезернистых пылеватых песков и серых хорошо промытых крупнозернистых песков. В основании разреза присутствую гравийные пески. Слоистость параллельная субгоризонтальная, полого-линзовидная, участками - пологоволнистая. Состав песков и их текстуры указывают на их накопление в обстановке проточного озера. Субаэральные перерывы или размывы отсутствуют, что свидетельствует об отсутствии разновозрастных плотин у озера. Для определения возраста озерных песков из них отобрано восемь образцов песков с 
интервалом 0.5-0.4 м (табл. 1, образцы DEALT19-13 - DEALT19-20). Полученные ОСЛ даты с небольшими инверсиями в пределах ошибки определения укладываются в возрастной диапазон от $16.2 \pm 1.3$ тыс. лет (RISØ-208814) до $11.2 \pm 0.9$ тыс. лет (RISØ208816). Все образцы оказались хорошо засвеченными, за исключением образца DEALT19-20 в кровле, возраст которого $14.3 \pm 0.9$ тыс. лет, возможно, завышен вследствие неполной засветки.

(2) Перевеянные светло-серые мелкозернистые пылеватые пески с нечетко выраженной параллельной пологонаклонной слоистостью. Основание пачки срезает слоистость в нижележащих озерных песках. Это несогласие фиксирует дефляционный контакт. Среди песков находится три эфемерных палеопочвы. Общая мощность субаэральной пачки 2.1 м. Из песков пачки с глубин 1.0, 1.5 и 2 м отобраны образцы песков DEALT19-23 - DEALT19-21, по которым без возрастных инверсий получено три ОСЛ даты (сверху вниз): $2.4 \pm 0.3$ (RISØ-208823), $4.6 \pm 0.4$ (RISØ-208822) и $10.2 \pm 0.8$ (RISØ-208821) тыс. лет (табл. 1). Анализ соотношений возрастов, полученных по кварцу и КПШ, показывает, что первая дата может быть “удревненной” вследствие неполной засветки зерен песка.

На правом берегу реки Чуя (рис. 4А), в районе 855 километра, федеральная автомобильная дорога Р-256 пересекает поле инверсионных гряд, сложенных материалом абляционной морены Куюктанарского ледника. В дорожной выработке (50.163510 с.ш., 88.286877 в.д., абсолютная высота 1746 м) вскрыт разрез одной из таких гряд (рис. 2). В обнажении протяженностью 36 м и высотой 6 м (рис. 4Б) находится темно-серый валунногалечный моренный диамиктон с алевропесчаным заполнителем. В нижней части обнажения, на высоте 1-1.5 м от его основания, прослеживается слой светло-серых гравийных песков с пологой косой флювиальной слоистостью и мощностью от 15 до 30 см, которые перекрываются тонкослоистыми белесыми алевритами мощностью от 10 до 25 см. В песках и алевритах наблюдаются постседиментационные структуры оползания и складки, формирование которых связано с процессом инверсионного оформления моренной гряды (Зольников, Мистрюков, 2008). Из флювиогляциальных песков взято два образца на ОСЛ определение абсолютного возраста (рис. 4B): DEAlt19-6.1 и DEAlt19-6.2. Полученные возраста составили $30.9 \pm 2.9$ (RISØ-208807) и 26. $7 \pm 2.0$ (RISØ-208808) соответственно (табл. 1). Из соотношения возрастов, полученных по кварцу и полевому шпату следует, что обе датировки могут быть “удревненными” вследствие неполной засветки зерен песка.

В правобережных береговых уступах Чуи к западу и востоку от устья р. Куюктанар также обнажаются комплексы основных (рис. 5А) и абляционных (5Б) морен. Еще один 
прослой флювиогляциального песка среди диамиктона абляционной морены опробован в основании инверсионной гляциальной гряды в точке с координатами 50.149860 с.ш. и 88.306740 в.д., абсолютная высота 1721 м (рис. 2). Здесь в береговом обрыве высотой 8 м над урезом р. Чуя (рис. 5В) вскрыт палевый моренный диамиктон с двумя маломощными (до 10 см) прослоями алевритового песка. Первый их них залегает на 30 см ниже бровки эрозионного вреза, второй - ниже бровки на 1 м. Из нижнего песчаного прослоя отобран образец DEAlT2019-7 (рис. 5Г). Его ОСЛ возраст составил $24.3 \pm 2.5$ тыс. л. (RISØ208809) (табл. 1). Взаимный контроль процедуры определения абсолютного возраста, выполненный по кварцу и КПШ показал, что полученная датировка является кондиционной.

\section{Обсуждение результатов}

Какие выводы могут быть сделаны из полученных нами данных? Для начала скажем, что полученные нами датировки для озерных песков в интервале 16-11 тыс. лет назад, хорошо согласуются с полученными ранее для них В.С.Шейкманом (2002) термолюминесцентными возрастами в $14.5 \pm 1.5$ и $13.5 \pm 1.5$ тыс. лет. В свою очередь, ОСЛ даты от 10 тыс. лет и моложе, характеризующие эоловые пески, хорошо согласуются с ранее проведенным радиоуглеродным датированием находящихся среди них палеопочв на правом и левом берегу р. Чуя. Первые такие датировки получены В.В.Бутвиловским (1993): $7460 \pm 70$ (СОАН 1692A), $6110 \pm 100$ (СОАН 1692В), $2490 \pm 100$ (СОАН 2377) и $1470 \pm 40$ (СОАН 2376; древесина в палеопочве) калиброванных лет. Их дополняет серия радиоуглеродных дат (Агатова, Непоп, 2017), частично полученная из тех же разрезов, что привел в своей работе В.В.Бутвиловский (1993): $8232 \pm 181$ (СОАН 8903), $5912 \pm 265$ (СОАН 9363), $4253 \pm 275$ (СОАН 9449), $3558 \pm 157$ (СОАН 8715), $3278 \pm 278$ (СОАН 9362), $1426 \pm 125$ (ИГАН 4139) и $1192 \pm 131$ (ИГАН 4140) калиброванных лет. Очевидно, что к пескам субаэральной пачки относятся и радиоуглеродные даты, полученные по корням деревьев и растительному детриту (Агатова, Непоп, 2017): $2403 \pm 253$ (ИГАН 4133), $1565 \pm 149$ (ИГАН 4131) и $325 \pm 176$ (ИГАН 4141) калиброванных лет. Нам представляется, что авторами этой публикации генезис вмещающих объекты датирования песков ошибочно принят за озерный. По всей видимости, аналогичная ошибка в фациальной диагностике первого сверху метра песков как озерных содержится и в работе (Рогожин, Платонова, 2002). На самом деле, все полученные этими авторами радиоуглеродные датировки растительных остатков также относятся к эоловым пескам: $250 \pm 90$ (ИГАН 1705), $990 \pm 160$ (ИГАН 1695), $1130 \pm 155$ (ИГАН 1701) и $1510 \pm 100$ (ИГАН 1704) калиброванных лет. 
Взаимный контроль процедуры определения абсолютного возраста, выполненный по кварцу и КПШ показал, что наиболее кондиционная дата для флювиогляциальных песков соответствует образцу с возрастом $24.3 \pm 2.5$ тыс. л. Два других образца оказались несколько недозасвеченными, поэтому их возраст немного удревнен. Тем не менее, все три полученных возраста согласованно указывают, что максимальная фаза развития Куюктанарского ледника, с которым связаны инверсионные гряды абляционных морен, пришлась на начало МИС 2.

Таким образом, существенный возрастной разрыв - около 8 тыс. лет - между формированием абляционных морен Куюктанарского ледника и расположенными восточнее озерными песками однозначно указывает на то, что озеро не являлось ледниково- или моренно-подпрудным. Его подпруда возникла около 16 тыс. лет назад при сходе гигантского Сукорского скального оползня, который перегородил южную часть долины р. Чуя напротив троговой долины Куюктанара. Размеры оползневого тела, его положение в сейсмоактивной зоне с современными и палеоаналогами, нахождение на линии активных разломов Курайской зоны с развитыми вдоль них поверхностными разрывами палеоземлетрясений относятся к числу критериев, которые позволяют связать оползень именно с сейсмогенным триггером (McCalpin, 1996).

Столь крупные по объему обвальные тела и оползни, согласно шкале сейсмической интенсивности ESI-2007 (Guerrieri, 2015), образуются при землетрясениях с интенсивностью X-XI баллов. Опыт авторских исследований в Прииссыккулье (Корженков, 2006; Деев, Корженков, 2016; Корженков и др., 2018; Korzhenkov, Deev, 2017), примеры из других сейсмоактивных регионов мира (Jibson, 1996; McCalpin, 1996; Keefer, 2002; Ugai et al., 2012), данные по очаговым зонам палеоземлетрясений района Чуйской и Курайской впадин и Алтайскому землетрясению 2003 г. (Рогожин и др., 2007, 2008), говорят о том, что крупные сейсмогравитационные структуры непосредственно маркируют очаговые зоны древних и исторических сейсмических событий. Расположение Сукорского скального оползня на простирании активных разломов, генерировавших палеоземлетрясения с $\mathrm{Mw}=6.6-7.6$ и интенсивностью от VIII до XI баллов во второй половине голоцена (Рогожин и др., 2008; Деев, 2028, 2019; Deev et al., 2017; Turova et al., 2020), убеждает нас в том, что сейсмическая подвижка 16 тыс. лет назад связана с одним из разломов Курайской зоны. Следовательно, установленный возраст палеособытия является наиболее древним из известных для КЗР и удревняет ее сейсмическую летопись почти на 10 тыс. лет.

Также важно, что сейсмогравитационные палеосейсмодислокации могут сохраняться в горных районах с полуаридным и аридным климатом, характерным для района Чуйской 
и Курайской впадин, на протяжении 16 тыс. лет. Современным ландшафтноклиматическим аналогом являются районы киргизского Тянь-Шаня, где в рельефе сохранились первичные разрывы палеоземлетрясений с возрастом 13-15 тыс. лет. (Thompson, 2001; Landgraf et al., 2016; Deev et al., 2018). Поэтому сохраняется надежда на обнаружение коррелятных Сукорскому скальному оползню поверхностных разрывов при дальнейших палеосейсмологических исследованиях в КЗР. Морфология Сукорского оползня указывает на то, что в его структуре могут участвовать и более молодые обвальные и оползневые тела. Их выделение также является перспективной задачей палеосейсмологических исследований. К примеру, установлено, что обвальными массами в 1 км восточнее устья Куюктанара перекрыта палеопочва с радиоуглеродным возрастом $213 \pm 11$ лет (ИГАН 1698) (Рогожин и др., 2008).

Озерный седиментогенез в обвально-подпрудном озере закончился около 10 тыс. лет назад. Сохранившиеся в районе плотины озерные пески, хорошо читаемые холмистый рельеф оползневых масс и грядовый рельеф абляционных морен говорят о том, что спуск этого озера не был мгновенным и не имел катастрофических последствий. Сохранность моренного комплекса с возрастом около 25 тыс. лет на узком участке между Курайской и Чуйской впадинами, где скорость и эродирующая деятельность катастрофического водного потока должны быть максимальными, свидетельствует, что в эпоху глобального LGM (20-23 тыс.л.н.) и позднее таких катастрофических сбросов воды из Чуйской впадины попросту не было.

Возрастной разрыв между абляционными моренами и основанием озерных песков говорит о том, что в Чуйскую впадину не распространялся последний ледниковоподпрудный озерный бассейн, реконструируемый в Курайской впадине в диапазоне 19-16 тыс. лет назад (Agatova et al., 2020). Это озеро должно было выклиниваться вверх по долине Чуи не далее кухтанарского участка, т.е. уровень этого озера не превышал абсолютной отметки 1750 м. В противном случае абляционные морены, имеющие, по нашим данным, более древний возраст, подверглись бы размыву. Было локальным и не распространялось по Чуйской долине выше Сукорского скального оползня и более позднее обвально-подпрудное озеро, чья плотина расположена в 12 км нижу устья Куюктанара. Его отложения датированы радиоуглеродным методом: $9690 \pm 110$ (СОАН 2378) и $8320 \pm 60$ (СОАН 2379) калиброванных лет. Образец древесины из перекрывающих их эоловых отложений имеет радиоуглеродный возраст $3320 \pm 50$ (СОАН 2380) калиброванных лет (Бутвиловский, 1993). Отсутствие озерной седиментации и развитие эоловых процессов с рубежа 10 тыс. лет говорит о том, что Сукорский скальный оползень не мог держать озеро, 
которое согласно Г.Г. Русанову (2010) занимало центральную часть Чуйской котловины в голоцене.

Наконец, более понятным становится и максимальный возраст археологических памятников, обсуждаемого участка долины р. Чуя. Все они относятся к постозерной стадии. Наиболее древние артефакты нестратифицированных памятников каменной индустрии Куяхтенар и Куяхтанар-2, находящихся в районе песчаных дюн к юго-востоку от Куюктанара (рис. 2), условно отнесены к позднему палеолиту (Деревянко, Маркин, 1987; Славинский и др., 2011). Возраст основания эоловых песков показывает, что эти памятники не древнее 10 тыс. лет и их следует относить к самому концу позднекаменного века.

\section{Заключение}

Проведенные исследования позволяют сделать следующие основные выводы.

1. Гигантский Сукорский скальный оползень возник 16 тыс. лет назад в результате землетрясения с интенсивностью IX-X баллов по шкале ESI 2007. Полученная датировка палеоземлетрясения является наиболее древней из надежно обоснованных возрастных рубежей палеосейсмических событий для КЗР.

2. Именно Сукорский оползень стал причиной формирования обвально-подпрудного озера, которое просуществовало в интервале 16-10 тыс. лет назад и постепенно спустилось, когда р. Чуя прорезала плотину.

3. Крупные сейсмогравитационные структуры в ландшафтно-климатических условиях, подобных району Чуйской и Курайской впадин, могут сохраняться в рельефе не менее 16 тыс. лет.

4. Максимальная фаза развития Куюктанарского ледника пришлась на начало МИС 2, а его абляционные морены имеют возраст около 25 тыс. лет.

5. Данные по определению абсолютного возраста и прекрасная сохранность инверсионных моренных гряд Куюктанарского ледника, холмистого рельефа оползневых масс, озерных песков в районе плотины указывают на то, что: а) в период глобального LGM (20-23 тыс.л.н.) из Чуйской котловины не происходило “мгновенных” сбросов больших объемов воды, порождавших мегапаводки в долинах Чуи и Катуни; б) в Чуйскую котловину не распространялись воды последнего Курайского озера ледниковоподпрудного озера с возрастом 19-16 тыс. лет назад; из всего спектра озерных террас на бортах Курайской впадины этому озеру принадлежат лишь наиболее низкие, с абсолютными отметками не превышающими 1750 м, а более высокие террасы, которые прослежены до абсолютных высот 2100-2200 м, принадлежат более древним озерным 
эпохам; в) оползневая плотина не могла держать озеро в Чуйской котловине на протяжении голоцена.

6. Археологические памятники, расположенные в районе перемычки между Чуйской и Курайской впадинами сформировались в постозерный период. Наиболее древние из них относятся к финалу позднекаменного века.

Авторы выражают свою признательность д.г.-м.н. Е.А. Рогожину и д.г.-м.н. О.В. Луниной, чьи конструктивные замечания позволили улучшить статью.

Исследования выполнены при финансовой поддержке РНФ (проект 19-17-00179). 


\section{Литература}

Агатова A.P., Непоп P.K. Соотношение позднепалеолитических памятников Чуйской котловины с геологическими следами ледниково-подпрудных озер позднего плейстоцена // Стратиграфия. Геологическая корреляция, 2017, т. 25, № 3, с. 1-17.

Агатова A.P., Непоп P.K., Высоцкий E.M. Сейсмогравитационные палеодислокации в долине реки Чаган (Юго-Восточный Алтай) // Геоморфология, 2006, № 4, с. 53-62.

Буслов М.М. Тектоника и геодинамика Центрально-Азиатского складчатого пояса: роль позднепалеозойских крупноамплитудных сдвигов // Геология и геофизика, 2011, т. 52, № 1 , с. 66-90.

Буслов М.М., Джен Х, Травин А.В., Отгонбаатар Д., Куликова А.В., Чен Минг, Глори С., Семаков Н.Н., Рубанова Е.С., Абилдаева М.А., Войтишек Е.Э., Трофимова Д.А. Тектоника и геодинамика Горного Алтая и сопредельных структур Алтае-Саянской складчатой области // Геология и геофизика, 2013, т. 54, № 10, с. 1600-1627.

Бутвиловский В.В. Палеогеография последнего оледенения и голоцена Алтая: событийно-катастрофическая модель. Томск: Изд-во Том. ун-та, 1993, 253 с.

Девяткин Е.В. Кайнозойские отложения и неотектоника Юго-Восточного Алтая. М.: Наука, 1965, 244 с. (Тр. ГИН АН СССР, вып. 126).

Деев Е.В. Неотектоника и палеосейсмичность внутригорных впадин северной части Центральной Азии (на примере Горного Алтая и Северного Тянь-Шаня): дис. ... д.г.-м.н. Новосибирск: ИНГГ СО РАН, 2018, 450 с.

Деев Е.В. Зоны концентрации древних и исторических землетрясений Горного Алтая // Физика Земли, 2019, № 3, с. 71-96.

Деев Е.В., Зольников И.Д., Турова И.В., Русанов Г.Г., Ряполова Ю.М., Неведрова Н.Н., Котлер С.А. Палеоземлетрясения в Уймонской внутригорной впадине (Горный Алтай) // Геология и геофизика, 2018, т. 59, № 4, с. 437-452.

Деев Е.В., орженков А.M. Палеосейсмологические исследования в эпицентральной зоне Кеминского землетрясения 1911 г. в Северном Тянь-Шане // Геология и геофизика, 2016, т. 57, № 2, с. 421-430.

Деревянко А.П., Маркин С.В. Палеолит Чуйской котловины. Новосибирск: Наука, 1987, 112 с.

Зольников И.Д. Гляциогенно обусловленные суперпаводки неоплейстоцена Горного Алтая и их связь с историей формирования отложений и рельефа Западно-Сибирской равнины // Бюлл. Комиссии по изучению четвертичного периода, 2009, № 69, с. 58-70. 
Зольников И.Д., Деев Е.В., Лямина В.А. Новые данные о четвертичном морфолитогенезе в Чуйской котловине (Горный Алтай) // Геология и геофизика, 2010, т. 51, № 4, с. 437-449.

Зольников И.Д., Деев Е.В., Котлер С.А., Русанов Г.Г., Назаров Д.В. Новые результаты OSL-датирования четвертичных отложений долины верхней Катуни (Горный Алтай) и прилегающей территории // Геология и геофизика, 2016, т. 57, № 6, с. 1194-1197.

Зольников И.Д., Мистрюков А.А. Четвертичные отложения и рельеф долин Чуи и Катуни. Новосибирск: Параллель, 2008, 180 с.

Корженков А.М. Сейсмогеология Тянь-Шаня (в пределах территории Кыргызстана и прилегающих районов). Бишкек: Илим, 2006, 290 с.

Корженков А.М., Абдиева С.В., Агатова А.Р., Арроусмит Р., Бауман Д., Вахрамеева П.С., Гладков А.С., Гуральник Б., Деев Е.В., Джумабаева А.Б., Казмер М., Керимбаева Д., Кольченко В., Кросби К., Лобова (Казанцева) Е.Ю., Лужанский Д.В., Мажейка Й.В., Мамыров Э., Меньшиков М.Ю., Морозова Е.А., Муралиев А.М., Нурманбетов К., Орлова Л.А., Павлис Т.Л., Поволоцкая И.Э., Порат Н., Рогожин Е.А., Родина С.Н., Родкин М.В., Сорокин А.А., Табалдиев К., Турова И.В., Усманов С.Ф., Фортуна А.Б., Чаримов Т.А., Шен Д., Юдахин А.С. Сильные исторические и палеоземлетрясения Прииссыккулья и их положение в структуре Северного Тянь-Шаня. М., ИФЗ РАН, 2018, 174 с.

Лескова Е.В., Еманов А.А. Иерархические свойства поля тектонических напряжений в очаговой области Чуйского землетрясения 2003 года // Геология и геофизика, 2013, т. 46, № 10, с. 1065-1072.

Неведрова Н.Н., Деев Е.В., Санчаа А.М. Глубинное строение и характеристики краевых структур Курайской впадины (Горный Алтай) по данным геоэлектрики с контролируемым источником // Геология и геофизика, 2014, т. 55, № 1, с. 119-132.

Неведрова Н.Н., Эпов М.И., Антонов Е Ю., Дашевский Ю.А., Дучков А.Д. Реконструкция глубинного строения Чуйской впадины Горного Алтая по данным электромагнитных зондирований // Геология и геофизика, 2001, т. 42, № 9, с. 1399-1416.

Окишев П.А. Рыхлые отложения в долине Чуй на участке между Чуйской и Курайской котловинами // Вопросы геологии и географии. Томск: Изд-во Томского ун-та, 1972, с. 202-204.

Окишев П.А. Динамика оледенения Алтая в позднем плейстоцене и голоцене. Томск: Изд-во Томского ун-та, 1982, 209 с. 
Рогожин Е.А., Богачкин Б.М., Нечаев Ю.В., Платонова С.Г., Чичагов В.П., Чичагова О.А. Следы сильных землетрясений прошлого в рельефе Горного Алтая // Геоморфология, 1999, № 1, с. 82-95.

Рогожин Е.А., Овсюченко А.Н., Мараханов А.В. Сильнейшие землетрясения на юге Горного Алтая в голоцене // Физика Земли, 2008, № 6, с. 31-51.

Рогожин Е.А., Овсюченко А.Н., Мараханов А.В., Ушанова Е.А. Тектоническая позиция и геологические проявления Алтайского землетрясения // Геотектоника, 2007, № 2, с. 3-22.

Рогожин Е.А., Платонова С.Г. Очаговые зоны сильных землетрясений Горного Алтая в голоцене. М.: ОИФЗ РАН, 2002, 130 с.

Русанов Г.Г. Обвально-подпрудное озеро в долине р. Чуи в конце позднего плейстоцена - начале голоцена (Горный Алтай) // Вопросы географии Сибири, вып. 22. Томск: Изд-во ТГУ, 1997, с. 18-25.

Русанов Г.Г. Изменения климата Чуйской котловины Горного Алтая в голоцене по фауне остракод // Успехи современного естествознания, 2010, № 10, с. 20-25

Русанов Г.Г., Деев Е.В., Ряполова Ю.М., Зольников И.Д. Палеогидротермальная активность разломов Горного Алтая по результатам датирования травертинов // Геология и минерально-сырьевые ресурсы Сибири, 2013, № 4 (16), с. 53-64.

Славинский В.С., Постнов А.В., Марковский Г.И., Басова Н.В., Зольников И.Д., Рыбин Е.П. Результаты разведки памятников палеолита в Алтайском крае и Республике Алтай в 2011 году // Проблемы археологии, этнографии, антропологии Сибири и сопредельных территорий. Новосибирск: Изд-во ИАЭТ СО РАН, 2011, т. XVII, с. 469-472.

Уломов В.И., Богданов М.И., Трифонов В.Г., Гусев А.А., Гусев Г.С., Акатова К.Н., Аптикаев Ф.Ф., Данилова Т.И., Кожурин А.И., Медведева Н.С., Никонов А.А., Перетокин С.А., Пустовитенко Б.Г., Стром А.Л. Общее сейсмическое районирование территории Российской Федерации. Пояснительная записка к комплекту карт ОСР-2016 и список населенных пунктов, расположенных в сейсмоактивных районах // Инженерные изыскания в строительстве, 2016, № 7, с. 49-121.

Федак С.И., Туркин Ю.А., Гусев А.И., Шокальский С.П., Русанов Г.Г., Борисов Б.А., Беляев Г.М., Леонтьева Е.М. Государственная геологическая карта Российской Федерации. Масштаб 1 : 1000000 (третье поколение). Серия Алтае-Саянская. Лист М-45 - Горно-Алтайск. Объяснительная записка. СПб.: Картографическая фабрика ВСЕГЕИ, 2011, 567 c. 
Шейнкман В.С. Возрастная диагностика ледниковых отложений Горного Алтая и их тестирование на разрезах Мертвого моря // Материалы гляциологических исследований. Вып. 93. М.: Изд-во ИГ РАН, 2002, с. 41-55.

Agatova A.R., Nepop R.K., Carling P.A., Bohorquez P., Khazin L.B., Zhdanova A.N., Moska P. Last ice-dammed lake in the Kuray basin, Russian Altai: New results from multidisciplinary research // Earth-Science Reviews, 2020, v. 205, p. 103183.

Agatova A.R., Nepop R.K., Slyusarenko I.Yu., Myglan V.S., Nazarov A.N., Barinov V.V. Glacier dynamics, palaeohydrological changes and seismicity in southeastern Altai (Russia) and their influence on human occupation during the last 3000 years // Quaternary International, 2014, v. 324, p. 6-19.

Adija M., Ankhtsetseg D., Baasanbat T., Bayar G., Bayarsaikhan C., Erdenezul D., Mungunsuren D., Munkhsaikhan A., Munkhuu D., Narantsetseg R., Odonbaatar C., Selenge L., Tsembel B., Ulziibat M., Urtnasan K.H. One century of seismicity in Mongolia (1900-2000): Ulaanbaatar, RCAG- DASE, 2003.

Carling P.A., Kirkbride A.D., Parnachov S., Borodavko P.S., Berger G.W. Late Quaternary catastrophic flooding in the Altai Mountains of south-central Siberia: a synoptic overview and introduction to flood deposit sedimentology, in Martini, I.P., Baker, V.R., and Garzon, G. (Eds.) Flood and Megaflood Processes and Deposits: Recent and Ancient Examples, Special Publication 32 of the IAS. Oxford: Blackwell Science, 2002, p. 17-35.

Chen M., Sun M., Cai K., Buslov M.M., Zhao G., Jiang Y., Rubanova E.S., Kulikova A.V., Voytishek E.E. The early Paleozoic tectonic evolution of the Russian Altai: Implications from geochemical and detrital zircon $\mathrm{U}-\mathrm{Pb}$ and $\mathrm{Hf}$ isotopic studies of meta-sedimentary complexes in the Charysh-Terekta-Ulagan-Sayan suture zone // Gondwana Research, 2016, v. 34, p. 1-15.

Chikov B.M., Zinoviev S.V., Deyev E.V. Post-Late Paleozoic Collisional Framework of Southern Great Altai // Acta Geologica Sinica, 2012, v.86, № 5, p. 1093-1104.

Deev E., Korzhenkov A., Turova I., Pavlis T.L., Luzhanskii D, Mažeika J., Abdieva S., Yudakhin A. Large ancient earthquakes in the western Issyk-Kul basin (Kyrgyzstan, northern Tien Shan) // Journal of Asian Earth Sciences, 2018, v. 166, p. 48-65.

Deev E.V., Turova I.V., Borodovskiy A.P., Zolnikov I.D., Oleszczak L. Unknown large ancient earthquakes along the Kurai fault zone (Gorny Altai): new results of paleoseismological and archaeoseismological studies // International Geology Review, 2017, v. 59, is. 3, p. 293-310.

Deev E., Turova I., Borodovskiy A., Zolnikov I., Pozdnyakova N., Molodkov A. Large earthquakes in the Katun Fault zone (Gorny Altai) - paleoseismological and archaeoseismological evidence // Quaternary Science Reviews, 2019, v. 203, p. 68-89. 
Delvaux D., Cloetingh S., Beekman F., Sokoutis D., Burov E., Buslov M.M., Abdrakhmatov K.E. Basin evolution in a folding lithosphere: Altai-Sayan and Tien Shan belts in Central Asia // Tectonophysics, 2013, v. 602, p. 194-222.

Guerrieri L. (Ed.) Earthquake Environmental Effect for seismic hazard assessment: the ESI intensity scale and the EEE Catalogue. Mem. Descr.lla Carta Geol. Italia, 2015. V. 97.

Jibson R.W. Use of landslides for paleoseismic analysis // Engineering Geology, 1996. V. 43. P. 291-323.

Herget J., Agatova A.R., Carling P.A., Nepop, R.K. Altai megafloods - The temporal context // Earth-Science Reviews, 2020, v. 200, p. 102995.

Keefer D.K. Investigating landslides caused by earthquakes - a historical review // Surv. Geophys., 2002, v. 23, p. 473-510.

Kokh S.N., Sokol E.V., Deev E.V., Ryapolova Yu.M., Rusanov G.G., Tomilenko A.A., Bul'bak T.A. Post-Late Glacial calcareous tufas from the Kurai fault zone (Southeastern Gorny Altai, Russia) // Sedimentary Geology, 2017, v. 355, p. 1-19.

Korzhenkov A.M., Deev E.V. Underestimated seismic hazard in the south of the IssykKul Lake region (Northern Tien Shan) // Geodesy and Geodynamics, 2017, v. 8, is. 3, p. 169180.

Landgraf A., Dzhumabaeva A., Abdrakhmatov K.E., Strecker M.R., Macaulay E.A., Arrowsmith J.R., Sudhaus H., Preusser F., Rugel G., Merchel S. Repeated large-magnitude earthquakes in a tectonically active, low-strain continental interior: the northern Tien Shan, Kyrgyzstan // Journal of Geophysical Research: Solid Earth, 2016, v. 121, p. 3888-3910.

McCalpin, J.P. (Ed.) Paleoseismology. San Diego: Academic Press, 1996.

Murray A.S., Thomsen K.J., Masuda N., Buylaert J.P., Jain M. Identifying wellbleached quartz using the different bleaching rates of quartz and feldspar luminescence signals // Radiation Measurements, 2012, v. 47, p. 688-695.

Murray A.S., Wintle A.G. The single aliquot regenerative dose protocol: potential for improvements in reliability // Radiation measurements, 2003, v. 37 (4-5), p. 377-381.

Rogozhin E.A., Bogachkin B.M., Nechaev Y.V., Platonova S.G., Chichagov V.P., Chichagova O.A. Paleoseismological investigations on the territory of Russian (Gorny) Altai // Journal of Earthquake Prediction Research, 1998, v. 7, p. 391-413.

Rudoy A.N. Glacier-dammed lakes and geological work of glacial superfloods in the Late Pleistocene, Southern Siberia, Altai Mountains // Quaternary International, 2002, v. 87, p. 119140.

Thompson S.C. Active Tectonics in the Central Tien Shan, Kyrgyz Republic (Ph.D. thesis). Seattle, Washington: University of Washington, 2001. 
Turova I., Deev E., Pozdnyakova N., Entin A., Nevedrova N., Shaparenko I., Bricheva S., Korzhenkov A., Kurbanov R., Panin A. Surface-rupturing paleoearthquakes in the Kurai Fault Zone (Gorny Altai, Russia): Trenching and geophysical evidence // Journal of Asian Earth Sciences, 2020, v.197. p. 104399.

Ugai K., Yagi H., Wakai A. (Eds.) Earthquake-induced landslides. Proceedings of the International Symposium on Earthquake-Induced Landslides, Japan, Kiryu, 2012. Springer, 2012. 


\section{ПОДРИСУНОЧНЫЕ ПОДПИСИ}

\section{к статье Е.В. Деева и др. “ВОЗРАСТ СУКОРСКОГО СЕЙСМОГЕННОГО ОПОЛЗНЯ ПО ДАННЫМ ОСЛ-ДАТИРОВАНИЯ: ЗНАЧЕНИЕ ДЛЯ ПАЛЕОСЕЙСМОЛОГИИ И ПАЛЕОГЕОГРАФИИ ГОРНОГО АЛТАЯ”}

Рис. 1. Элементы активной тектоники Курайской зоны разломов. А - активные разломы Курайской зоны. Б - Фрагмент Сукорского скального оползня. В - тело крупного скального оползня с южного склона Курайского хребта, к западу от долины р. Сокпанды. Г - правосдвиговое смещение апекса пролювиального конуса выноса от русла временного водотока, южный склон Курайского хребта. В - правосторонняя кулиса треугольных фасет тектонических уступов на южном склоне Курайского хребта, к юго-востоку от долины р. Куюктанар. E - дугообразные сбросы, осложняющие структуру северной части Чаганского массива. Ж - крупные тела осыпей вдоль тектонического уступа к востоку от троговой долины Куюктанара.

Рис. 2. Геоморфологическая схема района плотины обвально-подпрудного озера.

Рис. 3. Тренчинговые исследования и результаты ОСЛ определений возрастов озерных и эоловых песков в районе оползневой озерной плотины. А - вид на долину р. Чуя в районе Сукорского скального оползня. Виден песчаный массив, расположенный выше по течению р. Чуя от тела оползня и поля абляционных морен. Б - проходка экскаватором траншеи в эоловых и подстилающих их озерных песках. В - ветрогранник. Г - литологическая колонка, места отбора проб и результаты ОСЛ определения абсолютного возраста песков.

Рис. 4. Абляционные морены Куюктанарского ледника. А - Куюктанарский трог и грядовое поле абляционных морен. Б - разрез инверсионной гряды, сложенной абляционной мореной Куюктанарского ледника; белой штриховой линией обозначена линза флювиогляциальных гравийных песков и алевритов. В - положение точек отбора и номера образцов песков из флювиогляциального прослоя в абляционной морене.

Рис. 5. Морены Куюктанарского ледника. А - Взброс и гляциоотторженцы палеозойских коренных пород в основной морене. Б, В - обнажения абляционных морен в береговых правобережных уступах р. Чуя. Г - положение точек отбора и номера образцов песков из флювиогляциального прослоя в абляционной морене. 
Таблица 1. Результаты оптико-люминесцентного датирования. 
Таблица 1. Результаты оптико-люминесцентного датирования.

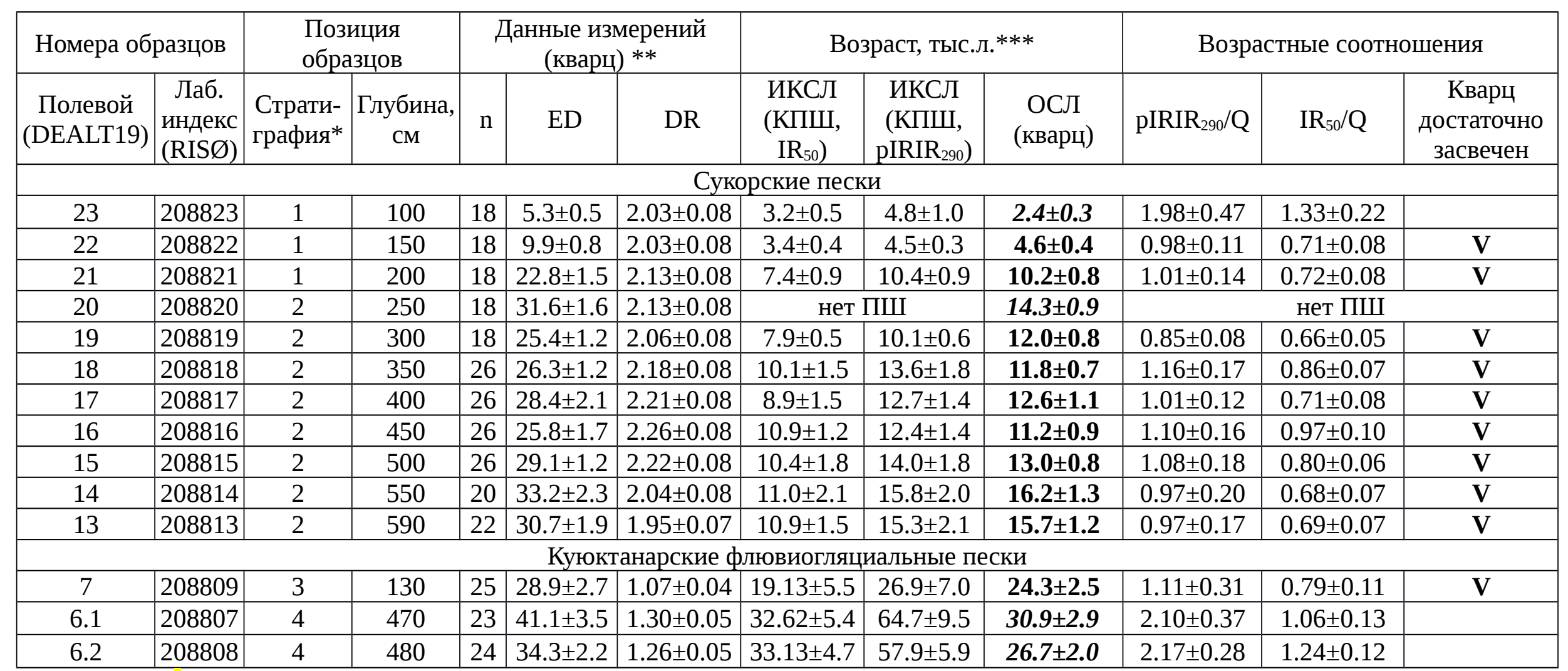

Примечания:

*Положение разреза, стратиграфическая позиция образцов:

1 - Расчистка в песчаном поле на правобережье Чуи выше по течению от куюктанарской морены; 50,14239 с.ш., 88,31686º в.д.

Эоловые пески (верхняя пачка).

2 -та же расчистка, озерные пески (нижняя пачка).

3 - Инверсионная гряда абляционной морены Куюктанарского ледника. Береговое обнажение правого берега р.Чуи; 50,14986 с.ш., $88,30674^{\circ}$ в.д. Внутриморенный флювиогляциальный песок.

4 - Придорожное обнажение на 855 км Чуйского тракта; 50,16355 с.ш., 88,28673ㅇ․․ Оплывневая морена Куюктанарского ледника. Слой внутриморенного флювиогляциального песка.

** n - число измеренных аликвот; ED - накопленная (эквивалентная) доза радиации (Грей); DR - скорость накопления дозы (Грей/тыс.л.).

***Курсивом выделены даты, для которых возможно увеличение возраста вследствие неполной засветки. 


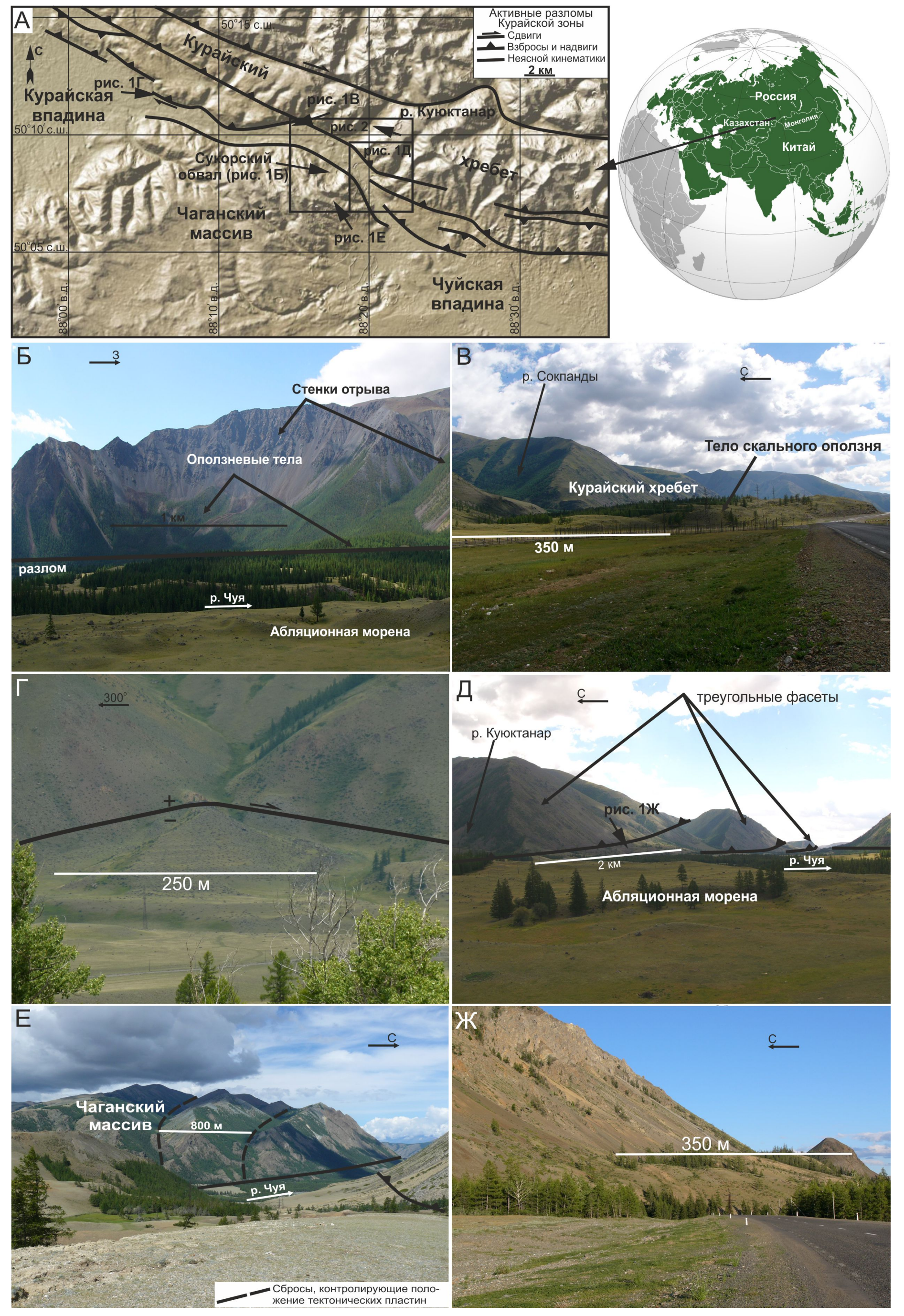




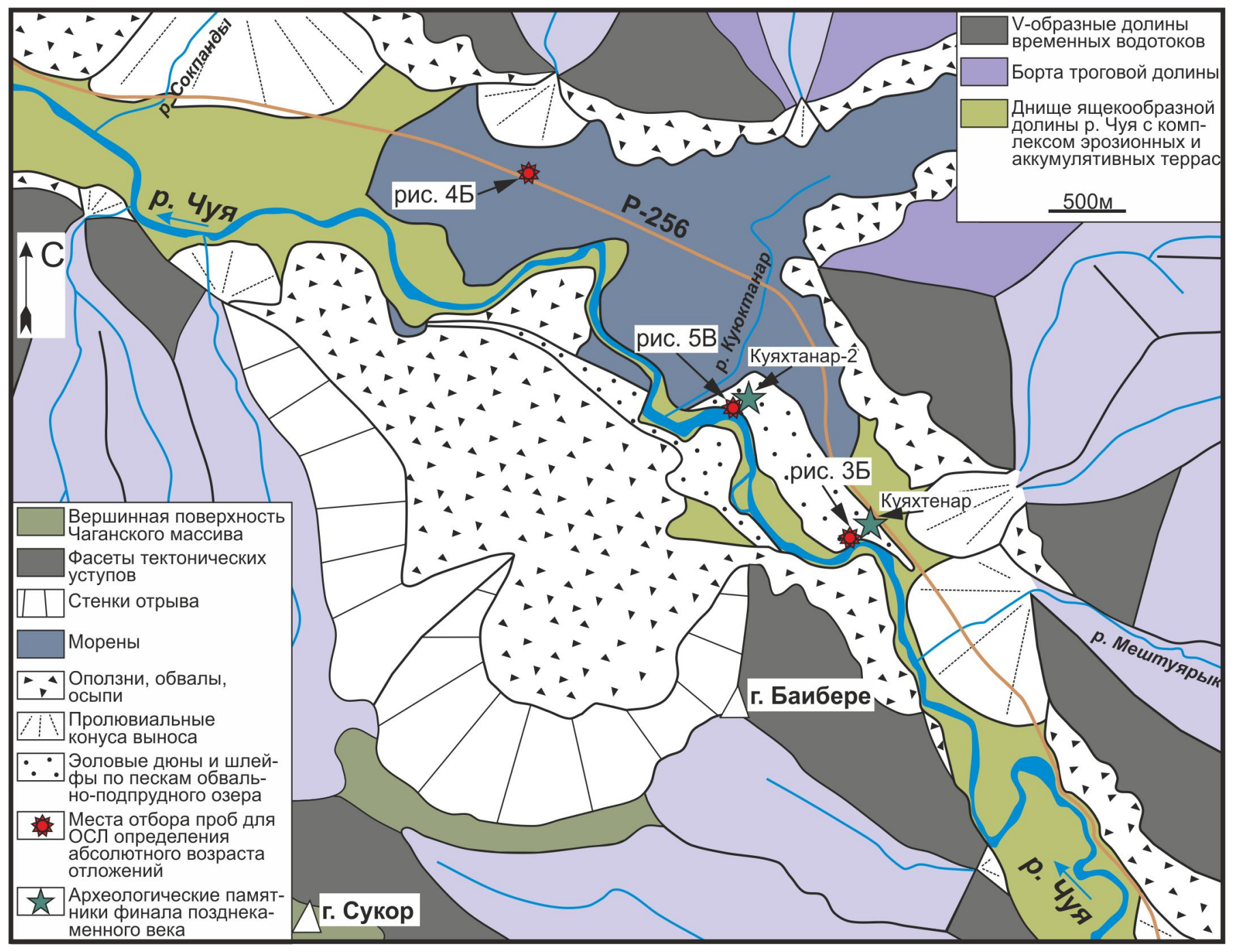



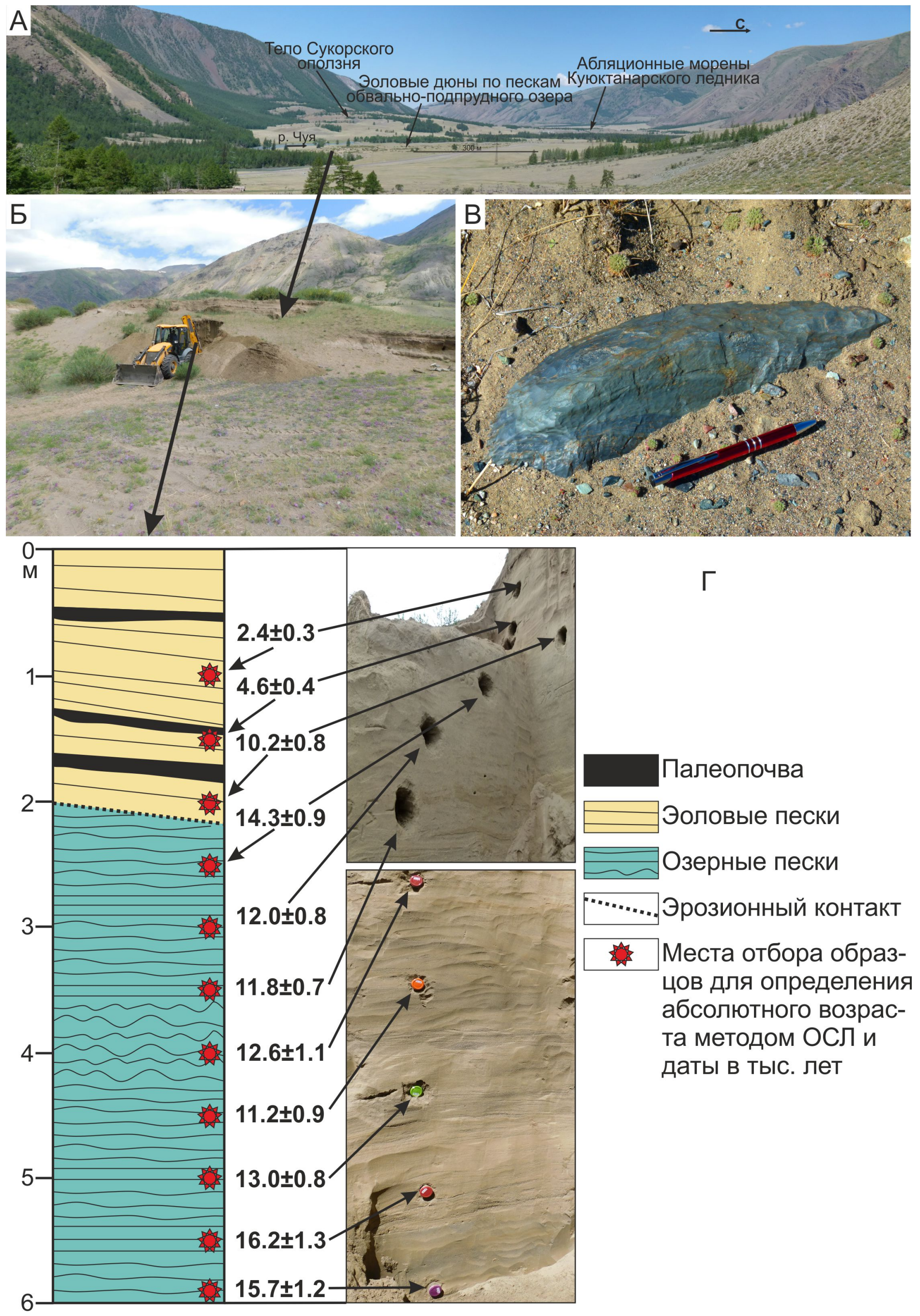

Палеопочва Э Эоловые пески ○ Озерные пески …...... Эрозионный контакт - Места отбора образцов для определения абсолютного возраста методом ОСЛ и даты в тыс. лет 

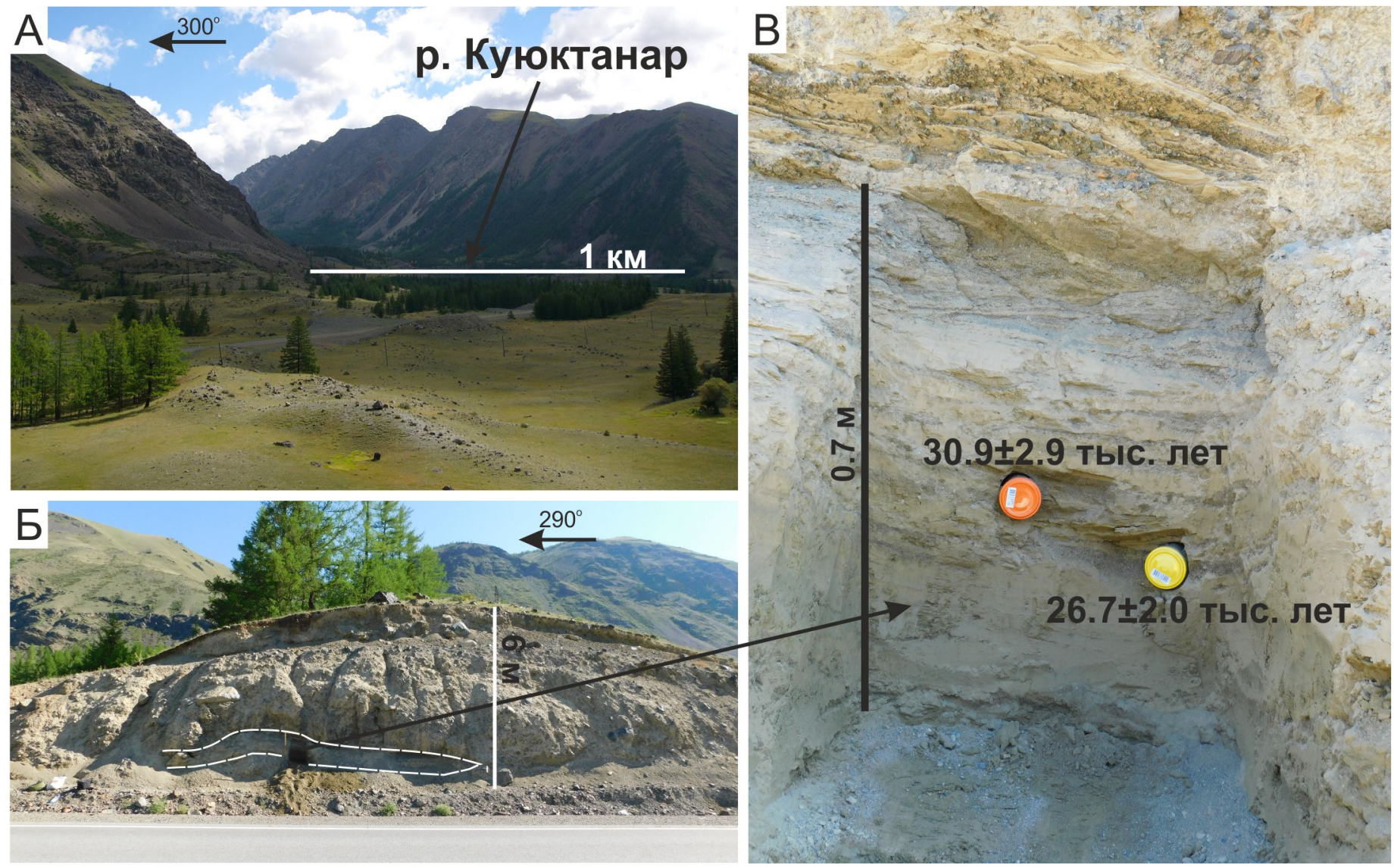


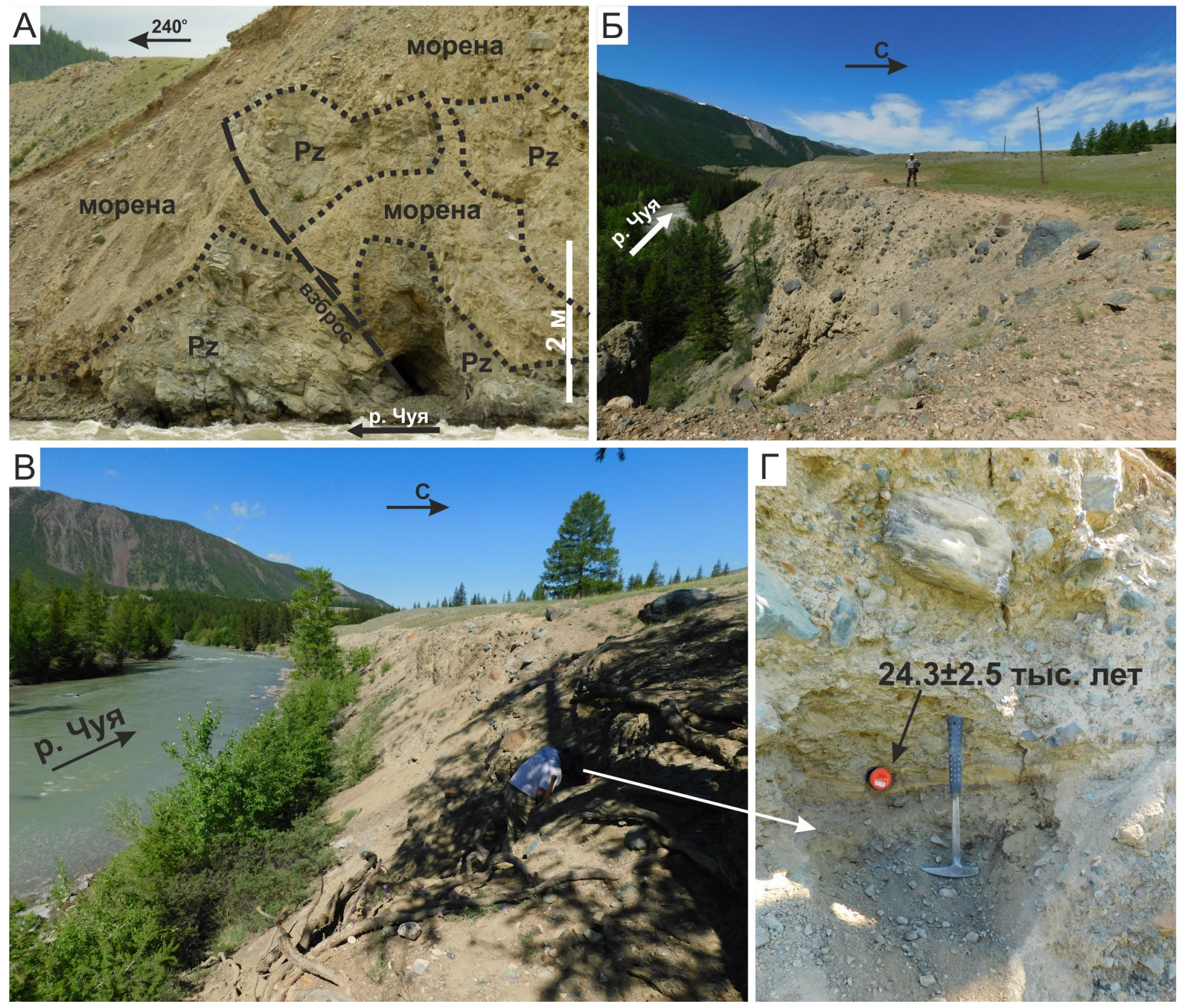

